\title{
Research on the Present Situation and Countermeasures of the Party Building Work for Postgraduates in New Era
}

\author{
Du Nana ${ }^{a}$, Tian Runfeng ${ }^{2}$ \\ Xi'an University of Posts and Telecommunications, Xi'an Shaanxi 710000 China \\ adunanapt@126.com
}

Keywords: New era; Graduate student; Party building; Innovation.

\begin{abstract}
The graduates of the new era shoulder the important mission of socialist builders and successors. Their ideological status and value orientation have a decisive influence on the social development of our country. Under this circumstance, graduate education should not only pay attention to the improvement of students' own abilities and qualities, but also actively strengthen the ideological and political education of graduate students. One of the focal points of ideological and political education work is party building work. With the increase in the number of graduate students in universities and the new requirements for party building work in the new era, party building work is facing new problems and challenges. The paper began to study this in order to propose a strategy for coping.
\end{abstract}

\section{Introduction}

General Secretary Xi Jinping pointed out in the nineteen major reports of the party that we should strengthen the construction of grass-roots party organizations. The grass-roots organization of the party is the basis for ensuring the implementation of the party's line and policy, policy and decision-making, and the construction of the grass-roots party organizations, such as schools, street communities and rural areas, as a strong Battle Fortress of the party's advocacy. In the new era, colleges and universities shoulder the important mission of cultivating the builders and successors of the socialist cause. As an important part of the party construction work at the grass-roots level of the University, the party construction of the graduate students is facing new problems and challenges. In the new era, it is necessary to strengthen the party construction work of the graduate students in Colleges and universities. We should conscientiously study and implement the nineteen spirit of the party, analyze and summarize the specific problems in the process of Party Construction in college graduate students, connect the theory with the practice, and try to explore the work mode which is in line with the specific requirements of the new era, and is the party construction work of the graduate students in the University. Key issues. At the same time, strengthening the party building work of graduate students is also the need to promote the comprehensive development of moral, intellectual and physical education for postgraduates.

\section{The problems of Party building work for Postgraduates in the new era.}

With the increase of the number of graduate students in universities and the new requirements of the party building work in the new era, the party construction work of graduate students in Colleges and universities is facing new problems and challenges, which are summarized in the following aspects.

\subsection{The awareness of student party members playing a vanguard role is deteriorating.}

Most of the Postgraduate Party members joined the Communist Party of China during the undergraduate period. They were able to move closely to the party organizations, report their ideas to the party organizations regularly, learn and implement the advanced theory and spirit of the party, 
learn from the knowledge of professional courses, join the enthusiasm of the community and other social practices. All of them are very active and protruding. After entering the postgraduate study stage, most of the student party members can still strictly regulate themselves, and play the exemplary role of good party members. However, some party members are willing to be plain and indifferent, and think that no accident is the best result. They do not play the vanguard role of Party members in all aspects of study, scientific research and practice. Some party members only pay attention to their own interests when participating in activities and performing party members' obligations; some party members not only do not. Fulfilling party members' obligations and responsibilities, and seriously damaging party members' image. It is undeniable that some Postgraduate Party members are only engaged in scientific research, lack of learning about the theoretical knowledge of the party, and do not restrict their behavior in daily learning and life with Party members' standards, and the consciousness of playing a vanguard and exemplary role is degenerating.

\subsection{The non standard setting of the student Party branch}

According to the thirtieth provisions of the party's basic organization in the fifth chapter of the constitution of the Communist Party of China, the Party branch should be set up separately in the grass-roots units with more than three formal party members. With less than three formal party members and without conditions to establish Party branches according to the requirements, the basic principles of leadership, management and activities can be facilitating in accordance with the nature of the Party branch. The Party branch should be set up jointly by two or three grass-roots units. Because the graduate student party members are distributed in different disciplines, different majors, different students' organizations and the age difference is big, the Party branch setting is unavoidable, which also brings some inconvenience to the smooth development of the party construction work.

\subsection{The activities of the Party branch are lack of new ideas}

In recent years, the activities of Party branches in Colleges and universities have gradually presented a trend of simplification and stylization of content and form, and lack of innovation. In general, the Party branch of the student party adopts the way of organizing the members of the Party branch to study, to learn and implement the party's knowledge of political theory, the latest policy and the spirit of documents and so on, and to write the experience of the party. However, with the development of the Internet, many students have experienced serious copying and plagiarism when writing their experience. In organizing Party Day activities, the form is old and lack of new meaning. It is generally concentrated on watching movies, inviting experts to the school to hold lectures, visiting the history museum, memorial hall and so on. These activities seldom relate to the actual study and life of the students, and the role of improving the party spirit of the student party members is not obvious. Graduate Party members lose interest in these traditional party day activities, so it is difficult to achieve good results.

\subsection{The prominent role of the new media in a double-edged sword}

In recent years, new media with the characteristics of rapid transmission, timely information acceptance, diversity of audience and outstanding individualization, are popular among college students. It has gradually become an indispensable tool in their study and life, but it also brings new opportunities and challenges to the party construction work at the grass-roots level in Colleges and Universities. On the one hand, the traditional party building education at the grass-roots level in Colleges and universities is almost all about the study of documents and the implementation of the spirit of documents. The single and old form of education and the content of education have seriously affected the teaching effect. The emergence of new media brings new opportunities to Party building at the grass-roots level in Colleges and universities, and further expands the time and space for Party building. On the other hand, the new media has broken the boundaries between the region and the country, and the increasing number of complex and unstable factors has brought new challenges to the party building at the grass-roots level in Colleges and universities. Although the postgraduate's world outlook, outlook on life and values have been relatively mature, some ideas of violence, 
hedonism and money are full of the whole network, enduring the impact of information from all sides for a long time, and the students are easily eroded by these ideas.

\section{The way to strengthen the party building work of postgraduate in the new era.}

\subsection{Strengthening the construction of teaching staff and improving the quality of personnel.}

In the new era, it is necessary to strengthen the construction of the party construction of the party construction work in the party construction work of the university graduate students, and to form a professional, standardized and systematic high level of teachers. Colleges and universities should strengthen the professional molding of teachers, strengthen teachers' study of political theory, enrich the knowledge reserve of teachers' political theory with the times, so as to improve the political and ideological quality of the teachers. For teachers to guide the work of Party building, teachers should be trained professionally. The teachers should guide the teachers according to the different grades and ages of the students, the different subjects, the different level of Ideological and political quality and the other different characteristics. At the same time, we should take party building guidance teachers and student Party branch secretaries as the starting point to enhance the overall professionalism of Party building teams and better serve the students.

\subsection{Enrich the educational content of Party members and innovate the form of Party members' education.}

In the nineteen major reports of the party, comrade Xi Jinping pointed out that the primary task of the party's ideological construction is to strengthen its ideals and beliefs. Therefore, the party building work of postgraduate students should be carried out firmly and firmly. The educational content of college student party members in the new period mainly includes the following aspects: one is ideological and political theory education, including the basic theoretical knowledge education of the party, legal morality and cultivation education, especially the important ideological education of socialism with Chinese characteristics in the new era of Xi Jinping, and the two is party education, which is the education of Party members and the others. Compared with the most significant characteristics of education, through education, the majority of the party members continue to strengthen the party spirit, enhance the students' patriotism emotion and the spirit of perseverance and hard struggle; three is the education of the party's line, policy and policy, unscramble the latest policy in time, strengthen the understanding and application of the students to the policy; four Education of knowledge and knowledge of science and culture. Secondly, to innovate the form of Party members' education, we can mainly take the following forms: first, we should conscientiously carry out the original work, study the original works, understand the principles of learning, learn the original book, understand the principles, study the Communist Manifesto and other books, actively carry out the discussion and exchange activities; two, actively organize student party members to watch a documentary film, Such as "the 200th anniversary congress commemorating the birth of Marx", "the fierce, my country" and other publicity films, education guides students to firmly establish "four correct understanding", constantly strengthen "four confidence", guide students to realize the unity of knowledge and correspondence, three is to carry out the theme Campus cultural activity, and let the students live in rich campus culture. The four is to carry out the practical activities of the theme education, organize the picture exhibition, the knowledge competition and the tour of the series of patriotic themes, so as to make the party members improve themselves and improve themselves in the process of learning.

\subsection{Strengthen organizational construction and optimize the establishment of student party branches.}

We must resolutely implement the nineteen spirit of the party, further optimize the establishment of the student Party branch, and continuously enhance the cohesion, creativity and combat effectiveness of the Party branch. The student Party branch should take on the important 
responsibility of education, management and supervision of the student party members directly, and organize, condense and serve the students. At the same time, it guides the majority of student party members to play the role of vanguard and model. According to the actual situation, according to the number of student party members, different disciplines, different majors, different grades, different students' organizations and other different characteristics, according to the principle of facilitating activities, playing a role and promoting scientific research and progress, the scientific setting up and rational optimization of the Party branch and the establishment of a sound and practical, practical and practical rule are set up. Fan system, scientific and rational, efficient and orderly work mechanism, fully mobilize and play a good role in the student Party branch.

\subsection{Strengthen the construction of campus network and improve the platform of Party building for new media.}

Under the new media environment, the opportunities and challenges coexist in the party building work of the graduate students. We should seize the new opportunity to make the new media a carrier of the innovation of the party construction, the platform for the basic party construction service and the bridge of communication between the party members at the grass-roots level. First, give full play to the leading role of the new media on public opinion and public opinion: first, to run a good new media party building platform, set up a standardized and orderly propaganda team, plan the party's theoretical knowledge to promote learning and cultural construction; two, to strengthen the construction of the network ideology and public opinion position, to realize the management of the student party members and the public opinion. Timely and benign interaction to avoid the situation of public opinion out of control; three is to consolidate and strengthen the coping and treatment of social hot issues, and to interpret some kinds of policies which are related to the vital interests of the graduate students, so that the graduate students can understand and understand them. Secondly, using the advantages of new media to consolidate and innovate the organization construction of the party: first, establish the electronic archives of student party members, do a good job of information collection and statistics, use the new media to set up a centralized information management platform for Party members in the party organization, so that the information of the party members can be displayed in an all-round way, and the two is to make use of the new media platform to do a good job. The party organize the life and work of the party, give full play to the advantages of the new media, innovate the methods of education and training for the student party members, and make full use of the new media to carry out various forms of criticism and self criticism to the party members.

\section{Summary}

Although there are many problems in the party construction work of graduate students in the new era, colleges and universities are constantly thinking and exploring the work of the party construction of graduate students, which greatly improves the quality and level of the party building work of the graduate students. However, at the same time, we must clearly realize that with the changes of the times, there will be new problems and challenges in the work of Party building for postgraduate students. In the work of Party building in the future, we should continue to sum up the lessons and lessons, take some measures to adapt to the new era, consolidate and innovate the methods and ways of the party building work of college graduate students with the times, so as to realize the standardization, systematization and systematization of the party organization development and the education of the party members. The students of the show absorb into the party organization, and allow the outstanding young people to realize their self value constantly under the training and guidance of the party organization, and realize the common progress of the party organizations and the individual members of the party. 


\section{Acknowledgements}

Foundation project: Postgraduate Innovation Fund of Xi'an Post and Telecommunications University.

\section{References}

[1] Du Hua. Design of assessment and evaluation system for Party building in Colleges and universities. [J]. ideological education research, 2017 (7): 93 - 96.

[2] Ma Yaling. The way to organize the life of Party branches in Colleges and universities in the "micro era". [J]. management observation, 2017 (5): 129 - 131.

[3] Pan Fuzhong. Exploration and practice of brand building in Party building in Universities [J]. Journal of college counselors, 2017 (3): 68 - 70.

[4] Maglan, Ma Ying Hui. To strengthen innovation and practice, and actively promote [J]. Education and teaching forum for postgraduate party building, 2014 (01).

[5] Ma Qiang, combined with the practice and exploration of the party building work of professional innovative graduate students, [J]. Education and occupation, 2012 (09). 